\title{
Photovoltaic-integrated review and expansion need in green building landscape for bridging the Malaysian RE policy
}

\author{
Mohd Effendi Amran ${ }^{1}$, Mohd Nabil Muhtazaruddin ${ }^{2}$, Nurul Aini Bani ${ }^{3}$, \\ Sharipah Alwiah Syed Abd Rahaman ${ }^{4}$, Nelidya Md Yusoff ${ }^{5}$, Mohd Hanapi Azizul ${ }^{6}$, \\ Firdaus Muhammad-Sukki ${ }^{7}$ \\ ${ }^{1}$ Engineering Services Division, Ministry of Health Malaysia, Malaysia \\ 1,2,3,4,5,6 Razak Faculty of Technology and Informatics, Universiti Teknologi Malaysia, Malaysia \\ ${ }^{7}$ School of Engineering, Robert Gordon University, United Kingdom
}

\section{Article Info \\ Article history: \\ Received Mar 20, 2019 \\ Revised May 30, 2019 \\ Accepted Jul 22, 2019}

\section{Keywords:}

Building-integrated PV(BIPV) Distributed generation (DG)

Energy efficiency index (EEI) Green building rating system (GBRS)

Net energy metering (NEM)

Photovoltaic (PV)

PV-type DG (PV-DG)

Renewable energy (RE)

\begin{abstract}
A literature review is presented specifically on the photovoltaic (PV) as a distributed generation (DG) integration approach and the extensiveness through renewable energy (RE) assessment criteria in current green building rating system (GBRS) to: delineate for further classification in terms of installed-capacity; identify the RE applications' intent / aim; and recommendation for PV-type DG (PV-DG) expansion needs. The paper aims to close the gap in knowledge, by an empirical review of current RE assessment criteria and to portray the expected evolution of RE for higher installed-capacity in ensuring the government key achievement can be achieved. In considering the expansion needs in GBRS, the optimal technique for PV-DG expansion-limit would serve as a conceptual bridge between expanding mechanism and realization of the Malaysian most recent RE policy specifically on the drastically increment of RE quota. These can be achieved since various DG optimization case studies have been presented and overcome with the improvement impact on the test system, in term of power loss reduction, increased efficiency and optimal cost outcome. Future analysis as well as research direction are proposed and linked with some of the previous optimization reviews in recent literature.
\end{abstract}

Copyright $(2020$ Institute of Advanced Engineering and Science. All rights reserved.

\section{Corresponding Author:}

Mohd Effendi Amran,

Engineering Services Division,

Ministry of Health Malaysia,

Level 3-7 Block E3, Parcel E, Precinct 1, 62590 Putrajaya, Malaysia.

Email: meffendi.amran@gmail.com

\section{INTRODUCTION}

Sustainability has been formally embraced in the Malaysia's Eleventh Plan where green growth will be a fundamental shift especially in the human capital, policy, and regulatory framework, green technology investment and financial instruments [1]. In line with the said initiative, Economic Plan Unit, EPU [1] had pointed the Ministry of Energy, Green Technology, and Water (now known as Ministry of Energy, Science, Technology, Environment and Climate Change Malaysia (MESTECC)) upheld by significant Agencies among respective Ministries to advance the development of green products and services in domestic market where measures to be undertaken which include of implementing Government green procurement for at least $20 \%$ by year 2020 , encouraging the green building developments and industries greening to stimulate green growth. Moreover, the concept of low energy and green building are also emphasized by the Malaysian government considering the environmental factors and conflicting of oil price at international market [2]. 
The green building developments are remarkably significant to the design of advanced and efficient integrated energy technologies to reduce electricity loads such as heating, cooling, etc. in the form of energy demand and the consumptions through the on-site renewable energy (RE) sources approach [3, 4]. Based on the essence of sustainable developments, the RE usage such as photovoltaic (PV) distributed generator (DG) is one of the most influentially common principles [5] and consequential approach in reducing the energy consumption in buildings [6] while having considered as a key component of the green building-based design of electricity generation capability [7]. Compared with conventional power utility generation, the technologies of RE are known to be less competitive, due to relatively high-cost maintenance and their intermittency of supply [8]. However, several advantages have been discovered from RE sources, i.e. high potential approach in the reduction of carbon emissions to the atmosphere and reduction in dependency on fossil fuel resources [9]. Besides, RE is also an option in avoidance of the safety problems derived from atomic power [10] in discovering the clean energy supply, resulting in more desirable to adopt RE power plants from a social point of view [11].

On the other hand, the green and efficient energy sector in Malaysia has set $2 \%$ share of RE installed-capacity in previous year (before 2015) while targeted for 5.5\% by year 2015 and finally striving towards $11 \%$ of standing quota to be achieved by 2020 [12]. In line with that, the Feed-in Tariff (FiT) implementation which has been commenced from $1^{\text {st }}$ December 2011 has foreseen the uprising RE quota towards $17 \%$ by 2020 [13]. However, the most recent, MESTECCs' 2019 initiative has launched a commitment to enlarge the green and efficient energy sector by increasing the percentage of renewable energy from $2 \%$ towards $20 \%$ for electricity generation by 2025 [14-16]. These scenarios highlight the latest commitment of Malaysian government to implement both green building development for government facilities and concurrently, streamline the additional quota for RE generation.

This paper aims at providing a review of recent PV-type DG (PV-DG) for building integration approach, which in advance, focusing towards the extensiveness in current selected green building rating system (GBRS). Then, the various requirement for current PV-DG maximum capacity from different selected GBRS are analyze for further classification in terms of installed-capacity. Subsequently, discussion and the recommendation are made on PV-DG expansion needs towards realization of the Malaysian most recent RE policy specific on the drastically increment of RE quota. The rest of this paper: Section 2 touches on PV-DG connection type and current approach in building-integrated PV (BIPV). Section 3 review the current RE assessment in selected GBRS via various optimal techniques. Section 4 describes the method for classifying the RE assessment. Section 5 presents the results and discussions. Section 6 concludes the paper.

\section{PV-DG CONNECTION TYPE AND THE CURRENT APPROACH IN BIPV INTEGRATION}

DG system is a decentralized power generation system comprising of power generators with smaller capacities (as compared to the conventional centralized power plants) directly embedded within distribution network, or situated in proximity to the points of energy consumption [17]. DG includes synchronous generators, induction generators, reciprocating engines, micro turbines, combustion gas turbines, fuel cells, solar PV, wind turbines and other small power sources which generally refers to small scale i.e. $1 \mathrm{~kW}-50 \mathrm{MW}$ electric power generators that produce electricity at a site close to the customer or that are tied to an electric distribution system [18]. The idea behind the connection of DG is to increase the reliability of power supplied to the customers, make use of a locally available resource and, if possible, reduce losses in transmission and distribution systems [19]. There are many reasons for a customer to install a DG such as generating customer's entire electricity supply for peak shaving or for standby generation, as a green power source, increased reliability, increased overall system capacity, reduction of power system losses and improved voltage profile $[18,20]$. The optimum DG placement and sizing will achieve maximum benefit, whereas nonoptimum could results in increase of power losses and affect the system voltage profile [20]. Advancements in technologies and environmental concerns have led to an increase in the reliance on RE based DGs [21].

DG system expansion trend was also observed in Asian developing countries, especially in Malaysia where energy services were part of the green industries promoted to encourage the utilization of carbonneutral and less carbon-intensive energy resources through the comprehensive of Low Carbon Society blueprint for Iskandar Malaysia 2025. Thus, DG energy system was recommended as a direct means for incorporating greener power production technologies in power supply services and industrial sectors [22].

Renewable based DG, for instance, PV-DG system, offer different types of integrating application according to [23-26] as follows: PV-diesel hybrid power system - uses supervisory control and data acquisition (SCADA) for control purposes. PV direct-coupled system - operates as mix power application when there is solar energy which supplies the output DC power directly to a DC load and also, operate in AC loads in many applications via PV inverter. Standalone PV combined with storage batteries - supply power and to maintain supplying loads even during nights, cloudy and certain weather condition. 
Small scale PV-DG generators that are tied to an electric distribution system as in [18] as well as grid-connected PV-DG, which also included the BIPV system as the terms of connection type [27]. Since energy is partially loss in the grid through long distribution lines, transformers and electronic components according to [28], grid integration studies had outlined the focus on increasing the efficiency of the system with changes to the configuration of the PV. Line losses reduction in distribution system are crucial to enhance the efficiency of obtained useful energy. This can be done by avoiding the improper and unnecessary integration and to backup resources of the grid with BIPV system.

Seyedmahmoudian, Kavalchuk [29], overcome with an important subject of BIPV which related with micro grid technology studies. This study highlighted that BIPV efficiency of the system can be increased if direct current (DC) operations selected in the proposed housing is accordance to the DC output power of PV storage system. On top of that, the study also focused at maximum power point tracking (MPPT) which plays an important role on the amount of energy which can be extracted from the production unit. The loss of output generated energy is throughout electronic components, transformers and long distribution lines in the grid. Thus, the best way to deal with grid and backup resources grid should avoid unnecessary integration with BIPV system. Huang, Eames [30] conducted a numerical experiment on the temperature rise of a BIPV application via the use of phase change material (PCM). Then different parameters, i.e. insolation, ambient temperature, system geometry and PCM were investigated through the proposed model. The study concluded that validated PV/PCM model provided a detailed insight into the thermal performance of PCM when used for PV temperature control applications.

Stamenić, Rajković [31] conducted an optimization for BIPV performance of powered electrolyzer inclusive with fuel cell system. The optimization comprises of a BIPV array, an inverter, a buck converter, a boost converter, an electrolyzer, a compressor, a battery, two fuel cell stacks, an $\mathrm{H} 2$ storage tank and a gas pressure regulator. The vertically mounted $8.2 \mathrm{kWp}$ nominal rating BIPV on the south facade of the building obtained the results which showed that the BIPV generated electricity was sufficient and the controller was able to operate the electrolyzer smoothly using the BIPV generated electricity and the configurations were viable. Zeng, Cao [32] presented two operation modes of multi-functional utility interface BIPV systems based on cascade converter. Grid-tied inverter under normal insolation was set as first operation mode, followed by while active power filter (APF) under low insolation as the second operation. The feasibility of the proposed system was granted via simulation result, and optimization by using the existing components in grid-connected BIPV systems could be achieved by the proposed system.

Ghani, Duke [33], proposed an artificial neural network (ANN) to estimate the conversion efficiency of a BIPVT system. The training, validation and testing of the network uses 288 simulation results which concluded that the ANN could be used for estimating the BIPVT output under various operating conditions. The ANN was considered fast and useful for interpolation of values within the limits of the training set, even though it was very time consuming and computationally intensive to get the necessary numerical simulation data after the training process. Liu and Duan [34] presented an evaluation method for energy efficiency of BIPV system with different power configurations. Strong irradiance and slight shade were presented by Case I, strong irradiance and severe shade presented by Case II, weak irradiance and slight shade presented by Case III, weak irradiance and severe shade presented by Case IV and lastly, electrical parameters mismatch of PV modules presented by Case V. The result representing by maximum available power of the system was equivalent to 5,315.6W, 2,818W, 195.43W and 60.17W for Case I, Case II, Case III and Case IV respectively which also indicated that the integrated converters could keep each PV module in an alternating current (AC)-module and PV-DC building module (PVDCBM) working at its own MPP. AC module and PVDCBM based systems were also found to be the most favorable solutions for BIPV systems due to their antimismatch and superior anti-shading features.

Fathabadi [35] developed PV inverter battery compartment of independent BIPV. Part of this inverter battery was configured in parallel at first, then energy efficiency was improved by configuring homogeneous array of PV modules. Using the Lambert $\mathrm{W}$ function, theoretical results which initially obtained is then compared with simulated results which found that energy efficiency of the converter-battery section of the PV increased with 10\%. Liu, Duan [36] proposed energy balance-based coordinate control and modelling of a PVDCBM based BIPV system. Comprised of PVDCBMs and a centralized inverter, also had an individual MPPT system for each PVDCBM in the system, the maximum power from the PV module was enabled to be extracted. To validate the model and the control strategy which have been developed, an experimental setup, consisted of two PVDCBMs and a centralized inverter, was built accordingly which managed to overcome with satisfactory dynamic response and the steady state performance results.

Celik, Karatepe [37] conducted analysis of spatially fixed PV array for maximum energy storage. Due to that, repayment period to ensure the PV fixed with the best electrical arrangement for the annual production amount and different configurations were analyzed. For electrical connection, $12.3 \%$ efficiency from $125 \mathrm{~W}$ nominal power represented by $12 \mathrm{PV}$ used series-parallel (SP) system and total cross tied (TCT) 
connection. Subsequently, the TCT connection was compared with SP system and various configurations with solar energy costs in Turkey $(\$ 0.5 / \mathrm{kWh})$ were taken for calculation of payback period, and the result found the average of 1.67 years. Different configurations and different electrical arrangements (i.e., SP and TCT) were varies with payback time where the efficiency of the system only possible to be increased by the changes of the PV configuration.

\section{CURRENT RE ASSESSMENT FOR PV-DG UTILIZATION IN SELECTED GBRS}

The GBRS being developed to provide rating points to identify the building meets criteria needs, and to demonstrate whether the building design is categorized as green [38]. GBRS evaluates the performances of the building and give rating award through each identical criteria and sub criteria [39]. The sustainable green building energy supply has established and implemented new policies to improve efficiency in energy consumption and to adopt and utilize new alternatives like RE system which lead beneficial for both developed and developing countries [5, 40]. A critical decision on the necessity of establishing RE system, together with selecting the type of RE system and source as well as the need of a combination of RE technology is very important from governments and businesses. In terms of sustainability as indicators, main RE technologies have been evaluated by several authors, for instance, comparison of wind power, hydropower, PV and geothermal energy by [41] with consideration of the price of generated electricity, efficiency of energy conversion, greenhouse gas emissions during the full life cycle of the technology, availability of renewable sources, water consumption, land requirements and social impacts. On top of that, [41] also concluded that wind power has the most favorable social impacts, lowest relative greenhouse gas emissions, and the least water consumption demands, but it requires high relative capital costs with more area of land. Strategies for a sustainable development of RE analyzed by [42] identified three major technological changes, i.e., efficiency improvements in energy production, energy savings on the demand side, and the replacement of fossil fuels with various sources of RE.

Through green building development in bigger context, the GBRS originated from Southeast Asian Countries (ASEAN), i.e. Malaysian Carbon Reduction Environmental Sustainability Tool (MyCREST), Green Building Index (GBI) Malaysia, GreenRE Malaysia, Green Ship Indonesia, Thai's Rating of Energy and Environmental Sustainability (TREES), and Green Mark Singapore are currently offer the encouragement for RE utilization through scoring credit in main assessment criteria. Initially, this has been partly pioneered by GBRS originated from United State of America (USA), i.e. Leadership in Energy and Environmental Design (LEED v4), which is remarkable as the great influencer for newer GBRS throughout the world [43]. The RE applications' intent / aim of these seven GBRS, are as shown in Table 1.

Table 1. The intent / aim of RE application between seven different GBRS

\begin{tabular}{cl}
\hline GBRS & \multicolumn{1}{c}{ Intent / Aim of Renewable Energy (RE) Application } \\
\hline MyCREST [44] & $\begin{array}{l}\text { To provide / maintain the generation of electricity from renewable resources and reducing the effect } \\
\text { to environment pollution by reducing greenhouse gas emissions. }\end{array}$ \\
GBI [45] & $\begin{array}{l}\text { Encourage use of RE. } \\
\text { Encourage the application of RE sources in buildings. } \\
\text { GreenRE [46] }\end{array}$ \\
Green Ship [47] & $\begin{array}{l}\text { Not stated. } \\
\text { On-site generation of RE can reduce the building development's power consumption from the grid } \\
\text { and carbon emissions. } \\
\text { Green Mark [48] }\end{array}$ \\
GREES [49] & $\begin{array}{l}\text { Gergy use. } \\
\text { To encourage the reduction of greenhouse gas emissions through the use of local and grid-source } \\
\text { RE technologies and carbon mitigation projects. }\end{array}$ \\
\hline LEED v4 [50]
\end{tabular}

Most of the GBRS aim in RE application can be described into prioritizing, encouraging, acknowledging effort in utilizing RE, and reducing environmental impact approached. To portray the current pattern of RE criteria setting and the scoring (credit) among these seven different GBRS, the holistic comparison among these GBRS are summarized as shown in Table 2. 
Table 2. The RE criteria setting and the scoring (credit) among selected seven different GBRS

\begin{tabular}{|c|c|c|c|}
\hline GBRS & Scoring Credit & \multicolumn{2}{|l|}{ RE Criteria Setting } \\
\hline & $4(\max )$ & \multicolumn{2}{|c|}{$3 \%$ from Total Building Energy Use } \\
\hline MyCREST & 3 & \multicolumn{2}{|c|}{$2 \%$ from Total Building Energy Use } \\
\hline [44] & 2 & \multicolumn{2}{|c|}{$1 \%$ from Total Building Energy Use } \\
\hline & 1 (min) & \multicolumn{2}{|c|}{$0.5 \%$ from Total Building Energy Use } \\
\hline & $5(\max )$ & \multicolumn{2}{|c|}{$2.0 \%$ of Max. demand or $40 \mathrm{kWp}$ (whichever greater) } \\
\hline & 4 & \multicolumn{2}{|c|}{$1.5 \%$ of Max. demand or $20 \mathrm{kWp}$ (whichever greater) } \\
\hline GBI & 3 & \multicolumn{2}{|c|}{$1.0 \%$ of Max. demand or $10 \mathrm{kWp}$ (whichever greater) } \\
\hline & 2 & \multicolumn{2}{|c|}{$0.5 \%$ of Max. demand or $5 \mathrm{kWp}$ (whichever greater) } \\
\hline \multirow{4}{*}{$\begin{array}{c}\text { GreenRE } \\
{[46]}\end{array}$} & 1 (min) & \multicolumn{2}{|c|}{$0.25 \%$ of Max. demand or $2 \mathrm{kWp}$ (whichever greater) } \\
\hline & $15(\max )$ & \multicolumn{2}{|c|}{$3 \%$ replacement of electricity by RE source } \\
\hline & 10 & \multicolumn{2}{|c|}{$2 \%$ replacement of electricity by $\mathrm{RE}$ source } \\
\hline & $5(\min )$ & \multicolumn{2}{|c|}{$1 \%$ replacement of electricity by $\mathrm{RE}$ source } \\
\hline \multirow{6}{*}{$\begin{array}{c}\text { Green Ship } \\
\text { [47] }\end{array}$} & $5(\max )$ & \multicolumn{2}{|c|}{$2.0 \%$ of Max. demand or $40 \mathrm{kWp}$ (whichever greater) } \\
\hline & 4 & \multicolumn{2}{|c|}{$1.5 \%$ of Max. demand or $20 \mathrm{kWp}$ (whichever greater) } \\
\hline & 3 & \multicolumn{2}{|c|}{$1.0 \%$ of Max. demand or $10 \mathrm{kWp}$ (whichever greater) } \\
\hline & 2 & \multicolumn{2}{|c|}{$0.5 \%$ of Max. demand or $5 \mathrm{kWp}$ (whichever greater) } \\
\hline & 1 (min) & \multicolumn{2}{|c|}{$0.25 \%$ of Max. demand or $2 \mathrm{kWp}$ (whichever greater) } \\
\hline & $($ For $E E I \geq 120) 6$ & \multirow{2}{*}{\multicolumn{2}{|c|}{ Replacement of building electricity by $3.0 \% \mathrm{RE}$}} \\
\hline \multirow{6}{*}{$\begin{array}{c}\text { Green Mark } \\
\text { [48] }\end{array}$} & $(\max )$ & & \\
\hline & 5 & \multicolumn{2}{|c|}{ Replacement of building electricity by $2.5 \% \mathrm{RE}$} \\
\hline & 4 & \multicolumn{2}{|c|}{ Replacement of building electricity by $2.0 \% \mathrm{RE}$} \\
\hline & 3 & \multicolumn{2}{|c|}{ Replacement of building electricity by $1.5 \% \mathrm{RE}$} \\
\hline & 2 & \multicolumn{2}{|c|}{ Replacement of building electricity by $1.0 \% \mathrm{RE}$} \\
\hline & 1 (min) & \multicolumn{2}{|c|}{ Replacement of building electricity by $0.5 \% \mathrm{RE}$} \\
\hline \multirow{4}{*}{$\begin{array}{c}\text { TREES } \\
\text { [49] }\end{array}$} & $4(\max )$ & \multicolumn{2}{|c|}{ RE not less than $3.5 \%$ of building energy cost } \\
\hline & 3 & \multicolumn{2}{|c|}{ RE not less than $2.5 \%$ of building energy cost } \\
\hline & 2 & RE not less than $1.5 \%$ of building $\mathrm{e}$ & hergy cost \\
\hline & $1(\min )$ & RE not less than $0.5 \%$ of building e & hergy cost \\
\hline & $5(\max )$ & Points $=$ & \\
\hline & 4 & Renewable energy generated $\%$ & \\
\hline LEED v4 & 3 & $1.5 \%$ & \\
\hline$[50]$ & 2 & Energy purchased or off set $\%$ & Max RE Capacity $=1.5 \%$ \\
\hline & 1 (min) & $25 \%$ & \\
\hline
\end{tabular}

\section{METHOD IN CLASSIFYING THE CURRENT RE ASSESSMENT IN SELECTED GBRS}

In this paper, an empirical review of RE assessment criteria from seven GBRS tools, i.e. MyCREST, GBI, GreenRE, GreenShip, TREES, Green Mark and LEED v4 are being referred to classify their current RE assessment criteria in terms of the capacity requirement and scoring credit. The considerations of the six ASEANs' originated GBRS selection are due to the fulfilment of the geographical location and climatic condition needs, which been highlighted in $[51,52]$ and also the need of environmental focus and socioeconomic of developing countries as in [53]. While, GBRS originated from USA i.e. LEED v4 is counted into the referral list of seven due to its' great influence on newer GBRS throughout the world [43].

However, in specific capacity requirement classification, TREES and Building for Ecologically Responsive Design Excellence - BERDE-OP (Philippines) are not considered in the scope due to mismatch of desired RE comparison information. TREES applied energy cost in the building as percentage for RE assessment [49]. While, BERDE-OP did not specify RE on its' GBRS tool [54]. Empirical observation is conducted via radar chart analysis.

\section{RESULTS AND DISCUSSION}

From Table 2, the minimum and maximum scoring from each and every GBRS are taken into analysis where, radar chart analysis is generated using these data and the results indicated the rank of scoring credit are as shown in Figure 1. Similarly, the RE criteria setting for all selected GBRS in Table 2 are also being used to generate radar chart to classify the RE capacity specification prior to each of different selected GBRS and the result is as shown in Figure 2. 


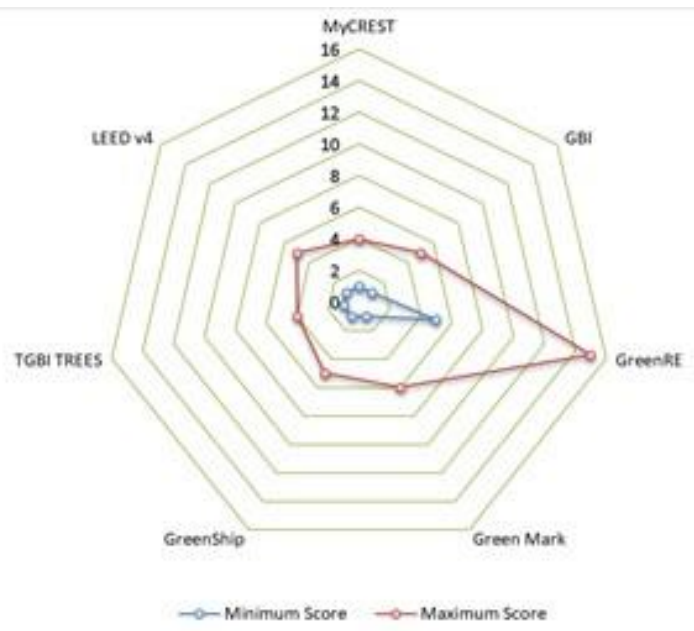

Figure 1. The radar chart for RE scoring credit

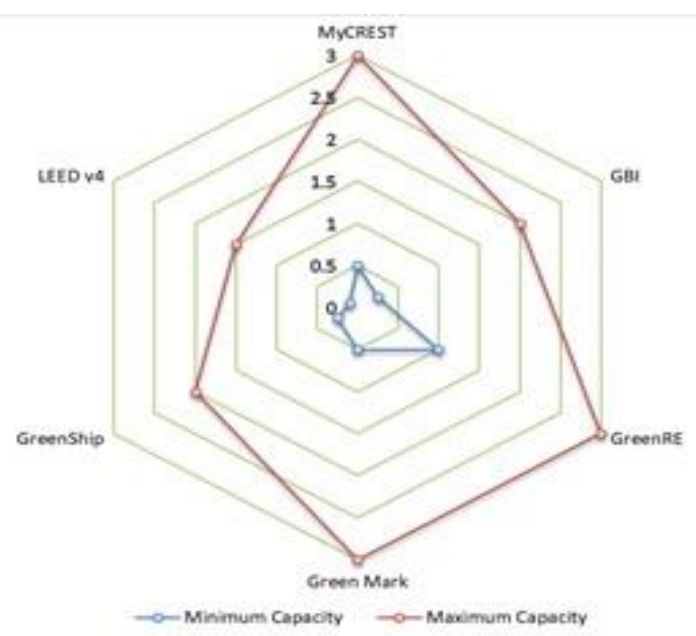

Figure 2. The radar chart for RE capacity

From Figure 1, the intensity of the highest score for RE application laid in the range between credit of 6 and four 4. In specific, 5 is the most imposed credit by the selected GBRS (i.e. by GBI, Green Ship and LEED v4). On the other hand, six GBRS (i.e. MyCREST, GBI, Green Mark, Green Ship, TREES and LEED v4) had imposed credit of 1 as the minimum score for RE setting for building. While, based on Figure 2, the highest RE capacity requirement were identified and classify into three groups as shown in Table 3 .

Table 3. The group for highest RE capacity among selected GBRS

\begin{tabular}{cc}
\hline GBRS & Max PV-DG percentage from MD prior to highest scoring \\
\hline MyCREST & $3 \%$ \\
GreenRE & \\
Green Mark & $2.0 \%$ or \\
GBI & $40 \mathrm{kWp}$ (whichever greater) \\
Green Ship & $1.5 \%$ \\
LEED v4
\end{tabular}

Thus, the intent of this RE assessments are aimed towards prioritizing, encouraging, acknowledging effort in utilizing RE, and reducing environmental impact which has portrayed the current imposed of small scale RE category as accordance to their respective assessment criteria. Consequently, by reconsidering at the 
above-mentioned most recent aim by MESTECC towards 2025 [14-16], the evolution of RE for higher installed-capacity is expected to be in placed to ensure the government key achievement can be fulfilled.

\section{CONCLUSION}

Based on the classification of PV-DG capacity in Table 1 and Table 3, the two previous-mentioned recent policies by MESTECC, i.e. to encourage the green building development for at least $20 \%$ by 2020 [2] and to enlarge the green and efficient energy sector by increasing the percentage of renewable energy from $2 \%$ towards $20 \%$ for electricity generation by 2025 [14-16], can result in the change of RE landscape in green building common practice and also will lead towards adoption of extreme expansion scale in RE utilization beyond the current GBRS base case in assessment criteria. From green building development perspective, the drastically increment of RE quota by $18 \%$ from original target will significantly overlapped the RE development which will subsequently increases the imposed of utilization such as PV-DG integration beyond current RE setting in GBRS application. The only scheme that allows higher capacity than any GBRS current setting for PV-DG building integration in Malaysia is Net Energy Metering (NEM) which applicable to all domestic, commercial and industrial sectors [55]. In addition, the previous-mentioned 20\% achievement target for RE utilization as declared in MESTECC initiatives of 2019, also involved with implementation of enhancing NEM and solar leasing which enable a greater access to RE sources [14].

However, DG can worsen the system performance [56] and lead to power losses and contribute to inefficient of RE transmitting if the proper assessment is not well considered [57]. The reason behind the issue is that the connection of DG via grid-connected integration onto radial distribution networks can change power flows from unidirectional to bidirectional affecting load-related losses [58]. Therefore, the right parameter setting for PV-DG integration specifically in minimal power losses within voltage regulation via the analytical approach of optimization is needed [18] to expand the PV-DG capacity beyond GBRS limit. Sustainable development can be assisted by RE technologies which also provide a solution to several energyrelated environmental problems. Hence, the improvement of the said technologies via optimal mechanism in this sense, constitute a suitable tool for solving complex problems in the field of RE systems [8].

\section{ACKNOWLEDGEMENTS}

The authors would like to express their appreciation to the Universiti Teknologi Malaysia (UTM) and Ministry of Education for funding this study via grants R.K130000.7740.4J295 and Q.K130000.3556.06G05.

\section{REFERENCES}

[1] EPU, E.P.U., "Eleventh Malaysia plan, 2016-2020: Anchoring growth on people." Malaysia: Prime Minister's Department, 2015.

[2] Moghimi, S., et al. "Building energy index (BEI) in large scale hospital: case study of Malaysia." in 4th WSEAS International Conference on Recent Reseaches in Geography Geology, Energy, Environment and Biomedicine, Corfu Island, Greece. 2011.

[3] Lund, H., A. Marszal, and P. Heiselberg, "Zero energy buildings and mismatch compensation factors". Energy and Buildings, 2011. 43(7): p. 1646-1654.

[4] Mwasha, A., R.G. Williams, and J. Iwaro, "Modeling the performance of residential building envelope: The role of sustainable energy performance indicators". Energy and buildings, 2011. 43(9): p. 2108-2117.

[5] Shi, L. and M.Y.L. Chew, "A review on sustainable design of renewable energy systems". Renewable and Sustainable Energy Reviews, 2012. 16(1): p. 192-207.

[6] GhaffarianHoseini, A., et al., "Sustainable energy performances of green buildings: A review of current theories, implementations and challenges". Renewable and Sustainable Energy Reviews, 2013. 25: p. 1-17.

[7] Deng, S., et al., "Case study of green energy system design for a multi-function building in campus." Sustainable Cities and Society, 2011. 1(3): p. 152-163.

[8] Banos, R., et al., "Optimization methods applied to renewable and sustainable energy: A review". Renewable and Sustainable Energy Reviews, 2011. 15(4): p. 1753-1766.

[9] Lu, Y., et al., "Renewable energy system optimization of low/zero energy buildings using single-objective and multi-objective optimization methods". Energy and Buildings, 2015. 89: p. 61-75.

[10] Strupczewski, A., "Accident risks in nuclear-power plants". Applied Energy, 2003. 75(1-2): p. 79-86.

[11] Skoglund, A., et al., "On the physics of power, energy and economics of renewable electric energy sources-Part II." Renewable Energy, 2010. 35(8): p. 1735-1740.

[12] Petinrin, J. and M. Shaaban, "Renewable energy for continuous energy sustainability in Malaysia". Renewable and Sustainable Energy Reviews, 2015. 50: p. 967-981.

[13] Hashim, H. and W.S. Ho, Renewable energy policies and initiatives for a sustainable energy future in Malaysia. Renewable and Sustainable Energy Reviews, 2011. 15(9): p. 4780-4787. 
[14] Initiatives, M. MESTECC Initiatives 2019 on RE quota. 2019 [cited on 15 ${ }^{\text {th }}$ January 2019]; Available from: https://www.mestecc.gov.my/web/wp-content/uploads/2019/01/MESTECC-Initiatives-2019-pg2-pg6-2.pdf.

[15] RE, P. National Renewable Energy Policy. 2019 [cited on $9^{\text {th }}$ May 2019]; Available from: http://www.seda.gov.my/policies/national-renewable-energy-policy-and-action-plan-2009/.

[16] MESTECC. MESTECC Initiatives 2019 on RE Policy. 2019; Available from: http://inisiatif.mestecc.gov.my/homepage_ms.html.

[17] Alanne, K. and A. Saari, "Distributed energy generation and sustainable development". Renewable And Sustainable Energy Reviews, 2006. 10(6): p. 539-558.

[18] Prabha, D.R. and T. Jayabarathi,"Optimal placement and sizing of multiple distributed generating units in distribution networks by invasive weed optimization algorithm". Ain Shams Engineering Journal, 2016. 7(2): p.683-694.

[19] Van Thong, V., J. Driesen, and R. Belmans, "Interconnection of distributed generators and their influences on power system". International Energy Journal, 2005. 6.

[20] Aman, M., et al., "A new approach for optimum DG placement and sizing based on voltage stability maximization and minimization of power losses". Energy Conversion and Management, 2013. 70: p. 202-210.

[21] Jaser, S.e., et al., Reassessment of voltage stability for distribution networks in presence of DG. 2016.

[22] Theo, W.L., et al., "Review of distributed generation (DG) system planning and optimisation techniques: Comparison of numerical and mathematical modelling methods". Renewable and Sustainable Energy Reviews, 2017. 67:p.531-573.

[23] El-Khattam, W. and M.M. Salama, "Distributed generation technologies, definitions and benefits". Electric Power Systems Research, 2004. 71(2): p. 119-128.

[24] Atwa, Y., et al., "Optimal renewable resources mix for distribution system energy loss minimization". IEEE Transactions on Power Systems, 2010. 25(1): p. 360-370.

[25] Isa, N.M., et al., A techno-economic assessment of a combined heat and power photovoltaic/fuel cell/battery energy system in Malaysia hospital. Energy, 2016. 112: p. 75-90.

[26] Parida, B., S. Iniyan, and R. Goic, "A review of solar photovoltaic technologies". Renewable and sustainable energy reviews, 2011. 15(3): p. 1625-1636.

[27] Eltawil, M.A. and Z. Zhao, "Grid-connected photovoltaic power systems: Technical and potential problems-A review". Renewable and Sustainable Energy Reviews, 2010. 14(1): p. 112-129.

[28] Biyik, E., et al., "A key review of building integrated photovoltaic (BIPV) systems". Engineering science and technology, an international journal, 2017. 20(3): p. 833-858.

[29] Seyedmahmoudian, M., et al. "Viable approaches for increasing the efficiency of buiding integrated photovoltaic systems". in Power Engineering Conference (AUPEC), 2015 Australasian Universities. 2015. IEEE.

[30] Huang, M., P. Eames, and B. Norton, "Thermal regulation of building-integrated photovoltaics using phase change materials". International Journal of Heat and Mass Transfer, 2004. 47(12-13): p. 2715-2733.

[31] Stamenić, L., M. Rajković, and Đ. Klisić, "Performance optimization of the BIPV powered electrolyser and fuel cells installation". Energy and Buildings, 2012. 51: p. 39-47.

[32] Zeng, G., M. Cao, and Y. Chen, "A multi-functional utility interface of BIPV systems based on cascade multilevel converter". Energy Procedia, 2012. 17: p. 356-365.

[33] Ghani, F., M. Duke, and J.K. Carson, "Estimation of photovoltaic conversion efficiency of a building integrated photovoltaic/thermal (BIPV/T) collector array using an artificial neural network". Solar Energy, 2012. 86(11): p. 3378-3387.

[34] Liu, B. and S. Duan, "Energy efficiency evaluation of building integrated photovoltaic systems with different power configurations". Simulation Modelling Practice and Theory, 2012. 29: p. 93-108.

[35] Fathabadi, H., "Increasing energy efficiency of PV-converter-battery section of standalone building integrated photovoltaic systems". Energy and Buildings, 2015. 101: p. 1-11.

[36] Liu, B., S. Duan, and T. Cai, "Modeling and coordinate control of photovoltaic DC building module based BIPV system". Solar Energy, 2012. 86(1): p. 482-488.

[37] Celik, B., et al., "Analysis of spatial fixed PV arrays configurations to maximize energy harvesting in BIPV applications". Renewable Energy, 2015. 75: p. 534-540.

[38] Swift Jr, J. and T. Lawrence, "GreenGuide: The design, construction, and operation of sustainable buildings." 2010, ASHRAE press, Atlanta.

[39] Castro-Lacouture, D., et al., "Optimization model for the selection of materials using a LEED-based green building rating system in Colombia". Building and Environment, 2009. 44(6): p. 1162-1170.

[40] Dagdougui, H., et al., "Modeling and optimization of a hybrid system for the energy supply of a "Green" building". Energy Conversion and Management, 2012. 64: p. 351-363.

[41] Evans, A., V. Strezov, and T.J. Evans, "Assessment of sustainability indicators for renewable energy technologies". Renewable and sustainable energy reviews, 2009. 13(5): p. 1082-1088.

[42] Lund, H., "Renewable energy strategies for sustainable development". Energy, 2007. 32(6): p. 912-919.

[43] Rahardjati, R., M.F. Khamidi, and A. Idrus, The level of importance of criteria and sub criteria in green building index malaysia. 2010.

[44] MyCREST, C. Malaysian Carbon Reduction \& Environmental Sustainability Tool - Operation and Maintenance Stage. 2015 [cited on $9^{\text {th }}$ May 2019]; Available from: http://www.cidb.gov.my/index.php/en/focusareas/sustainable-construction.

[45] GBI, Green Building Index. 2013, Retrieved. 
[46] GreenRE. GreenRE for Existing Non-Residential Building (ENRB V3.1). 2018 [cited on 9 th $^{\text {th }}$ My 2019]; Available from: https://greenre.org/rating-tools.html.

[47] Greenship, G., Greenship Existing Building for Existing Building: Benchmark Summary. Green Building Council Indonesia, Jakarta, Indonesia, 2011.

[48] GreenMark. BCA Green Mark for Existing Non-Residential Buildings (GM ENRB: 2015). 2015 [cited on $2^{\text {nd }}$ January 2019]; Available from: https://www.bca.gov.sg/GreenMark/green_mark_criteria.html.

[49] TREES. Thai's Rating of Energy and Environmental Sustainability for Existing Building (TREES-EB): Operation and Maintenance. 2017 [cited on $9^{\text {th }}$ May 2019]; Available from: http://www.tgbi.or.th/tag/show/4.

[50] LEED, U.v., LEED v4 for Building Operations and Maintenance. Acedido em: http://www.usgbc. org/resources/leed-v4-building-operations-and-maintenance-current-version, 2016.

[51] Glavinich, T.E. and T.A. Taylor, Contractor's guide to green building construction: management, project delivery, documentation, and risk reduction. 2008: Wiley Online Library.

[52] Shi, Q., "Strategies of implementing a green building assessment system in mainland China." Journal of Sustainable Development, 2009. 1(2): p. 13.

[53] Hill, R., P. Bowen, and L. Opperman, Sustainable building assessment methods in South Africa: an agenda for research. 2002.

[54] BERDE-OP. BERDE GBRS - OPERATIONS VERSION 2.2.0, Philippine Green Building Council, Official Release 31 August 2018. 2018 [cited on $9^{\text {th }}$ May 2019]; Available from: http://berdeonline.org/\#berde-gbrs-operations.

[55] NEM, G. Technical Guideline for Connection of Indirect Solar PV Power Generation for Net Energy Metering. 2019 [cited on $15^{\text {th }}$ February 2019]; Available from: http://www.seda.gov.my/reportal/nem/.

[56] Muhtazaruddin, M.N.B., et al. "Optimal distributed generation and capacitor coordination for power loss minimization. in T\&D Conference and Exposition", 2014 IEEE PES. 2014. IEEE.

[57] Amran, M.E. and M.N. Muhtazaruddin, "Assessment of renewable Distributed Generation in Green Building Rating System for public hospital". International Journal of Engineering and Technology(UAE), 2018. 7(3): p. 4045.

[58] Quezada, V.M., J.R. Abbad, and T.G.S. Roman, "Assessment of energy distribution losses for increasing penetration of distributed generation". IEEE Transactions on Power Systems, 2006. 21(2): p. 533-540. 